\title{
32. GEOCHEMISTRY OF CARBON: DEEP SEA DRILLING PROJECT LEGS 42A AND 42B
}

\author{
J.G. Erdman and K.S. Schorno, Phillips Petroleum Company, Bartlesville, Oklahoma
}

\section{INTRODUCTION}

A total of 14 core sections from Legs $42 \mathrm{~A}$ and $42 \mathrm{~B}$ were received through the JOIDES Organic Geochemistry Advisory Panel for organic geochemical characterization. The location of each site is given in Figure 1. One section was taken at Site 376 on the Florence Rise to the southwest of Cyprus; three sections at Holes 378 and 378A from the Cretan Basin in the Aegean Sea; and ten sections at Holes 380 and $380 \mathrm{~A}$ from near the Bosporus in the Black Sea. Conclusions presented herein are based on the following determinations: (1) the amount and type of organic matter present (Table 1); (2) carbon isotope ratio values of the lipid and kerogen fractions (Table 2); (3) elemental analyses of total nitrogen in the sediment (Table 1) and carbon, hydrogen, nitrogen, sulfur content of the lipid fraction (Table 2); and (4) the ratio of odd-to-even $n$-alkanes (Table 2).

\section{SAMPLING AND STUDY PROCEDURES}

The sampling and study procedures have been reported in an earlier DSDP Volume 41 (Erdman and Schorno, in press) and are reviewed in Figure 2. All samples were treated similarly. In order to minimize post-sampling alteration of the organic fraction, all samples were kept frozen until initiation of the organic analysis.

\section{CORE CHARACTERIZATION}

The significance of geochemical data generated in the DSDP program depends upon the physical integrity and freedom of contamination of the samples. It is essential, therefore, for each sample, to resolve the question of whether the core is representative of the actual depth interval or is a mixture of stratigraphic intervals and suspect throughout in regard to contamination with extraneous organic matter such as pipe dope or refined oil. In regards to the former, in this laboratory, disturbance as a consequence of coring is determined by splitting linearly by sawing the frozen core, milling the surface of each halved core to remove surface distortions and smearing caused by the splitting processes, and observing the core for disturbance and mixing. The halved section of each core is photographed in both black and white and color. Some drilling disturbance is evident in practically every core studied as shown by distortions at the core-sleeve interface as illustrated in Figure 3(A). In this case, removal of the outer portion of the core eliminates the danger of contamination. Extensive disturbances are observed by large lumps admixed with homogenized sediment or by a squeezing of one section into a second as illustrated in Figure 3(B). In this case, it is necessary to excise the lumps using the photographs as a guide. Very little disturbance was encountered in these cores. Sections 42B-380-25-0 and 42B-380A-22-4 show the extensive disturbance. In other sections, for example in 42A-378-6-2 and 42B-380A-22-4 the degree of observed inhomogeneities is questionable.

In regard to the core sections used in this study, major disturbances with lumps of the original bedded sediment intact are observed in Sections 42A-378-6-2, 42B-380-25-0, 42B-380A-47-4, the remaining cores showed only minor edge distortions.

\section{RESULTS AND DISCUSSION}

Only one core was studied from Site 376 to the southwest of Cyprus on the Florence Rise. The upper Miocene sediment is dolomitic with a relatively high organic content, $1.18 \%$ as organic carbon. The hole temperature near the sampling point was $16^{\circ} \mathrm{C}$ and was probably never higher than that during its geologic

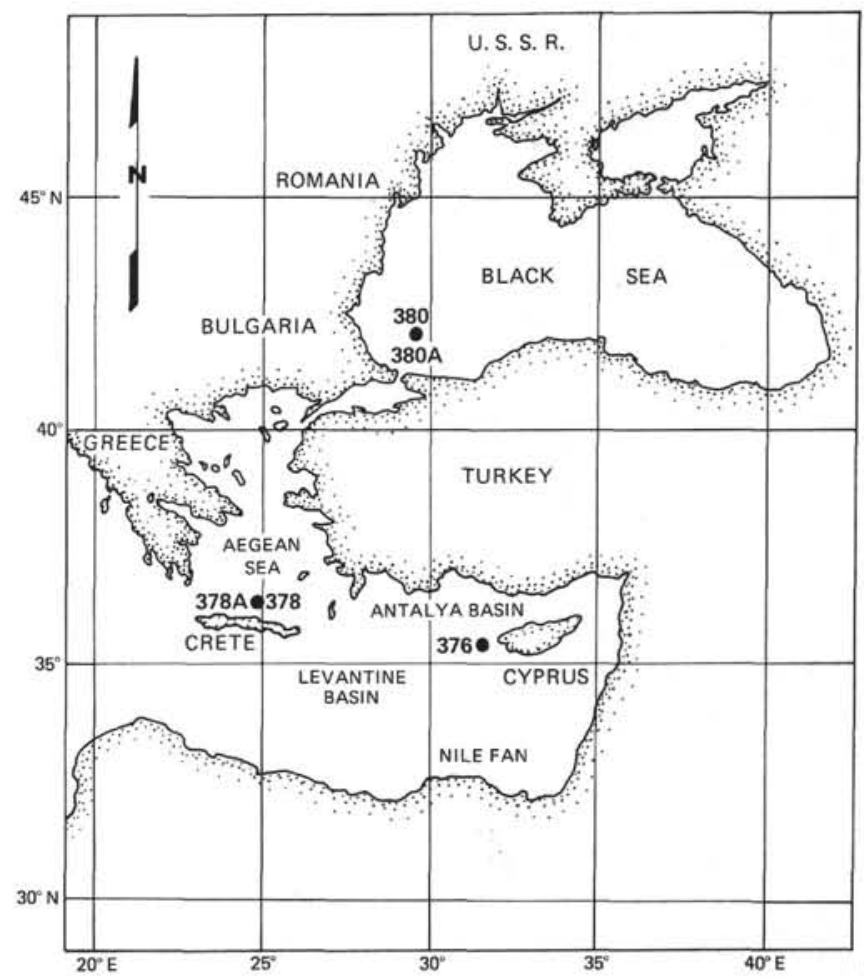

Figure 1. Legs $42 A$ and $42 B$ drill sites: Location of holes from which samples for geochemical study were observed. 
TABLE 1

Geochemical Characterization Data for Samples From DSDP, Legs 42A and B for Total Homogenized Sediment

\begin{tabular}{|c|c|c|c|c|c|c|c|c|c|}
\hline \multirow[b]{2}{*}{$\begin{array}{l}\text { Site-Core- } \\
\text { Section }\end{array}$} & \multirow[b]{2}{*}{$\begin{array}{c}\text { Geologic } \\
\text { Age }\end{array}$} & \multirow[b]{2}{*}{$\begin{array}{l}\text { Subbottom } \\
\text { Depth (m) }\end{array}$} & \multicolumn{2}{|c|}{ Carbonate } & \multicolumn{2}{|c|}{ Organic Carbon } & \multicolumn{2}{|c|}{ Nitrogen } & \multirow{2}{*}{$\begin{array}{l}\text { Kerogen } \\
\delta \mathrm{C}^{13} \text { PDB }\end{array}$} \\
\hline & & & $\begin{array}{c}\text { Carbon } \\
\text { (wt \%) }\end{array}$ & $\begin{array}{l}\mathrm{CaCO}_{3} \\
(\text { wt \%) }\end{array}$ & $\begin{array}{l}\text { Total } \\
\text { (wt \%) }\end{array}$ & $\begin{array}{r}\text { Lipid } \\
\text { (wt \%) }\end{array}$ & $\begin{array}{l}\text { Inorganic }^{a} \\
\quad(p p m)\end{array}$ & $\begin{array}{c}\text { Organic }^{b} \\
(\mathrm{ppm})\end{array}$ & \\
\hline $376-9-2$ & U. Miocene & $76.8-76.9$ & 2.19 & 18.25 & 1.18 & 0.015 & 39 & 361 & -22.4 \\
\hline $378-6-2$ & Pliocene & $143.9-144.0$ & 4.80 & 40.00 & 0.81 & 0.020 & 96 & 304 & -23.2 \\
\hline $378 \mathrm{~A}-14$ & Quaternary & $51.9-52.0$ & 4.59 & 38.25 & 0.83 & 0.001 & 60 & 240 & -23.1 \\
\hline $378 A-3-3$ & Pliocene & 297.4-297.5 & 0.71 & 5.92 & 0.67 & 0.001 & 30 & 270 & -21.7 \\
\hline $380-4-0$ & Pleistocene & 29.4-29.6 & 2.56 & 21.33 & 0.49 & 0.015 & 113 & 187 & -24.1 \\
\hline $380-25-0$ & Pleistocene & $228.0-228.1$ & 0.09 & 0.75 & 1.24 & 0.025 & 500 & 500 & -26.0 \\
\hline $380 A-3-3$ & Pleistocene & $355.8-355.9$ & 0.80 & 6.67 & 1.91 & 0.101 & 600 & 700 & -25.5 \\
\hline $380 \mathrm{~A}-12-1$ & Pleistocene & $438.0-438.2$ & 0.73 & 6.08 & 0.94 & 0.021 & 551 & 649 & -25.2 \\
\hline $380 \mathrm{~A}-22-4$ & Pleistocene & $537.4-537.5$ & 2.40 & 20.00 & 1.07 & 0.029 & 328 & 672 & -26.0 \\
\hline $380 A-38-4$ & Pleistocene & $679.8-679.9$ & 0.10 & 0.83 & 2.33 & 0.049 & 1000 & 1300 & -25.9 \\
\hline $380 \mathrm{~A}-47-4$ & Pleistocene & $764.9-765.0$ & 2.35 & 19.58 & 2.03 & 0.054 & 500 & 1300 & -24.2 \\
\hline $380 \mathrm{~A}-55-2$ & Pleistocene & $837.9-838.0$ & 0.28 & 2.33 & 2.21 & 0.059 & 580 & 1420 & -24.6 \\
\hline $380 A-64-5$ & Pleistocene & $927.9-928.0$ & 1.60 & 13.33 & 3.07 & 0.109 & 370 & 1130 & -21.9 \\
\hline $380 \mathrm{~A}-76-3$ & Pleistocene & $1039.1-1039.2$ & 0.52 & 4.33 & 1.10 & 0.012 & 300 & 300 & -24.4 \\
\hline
\end{tabular}

${ }_{\mathrm{b}}^{\mathrm{a}}$ As determined by the half Kjeldahl which is representative of ammonium nitrogen only.

$\mathrm{b}$ As determined by the full minus the half Kjeldahl.

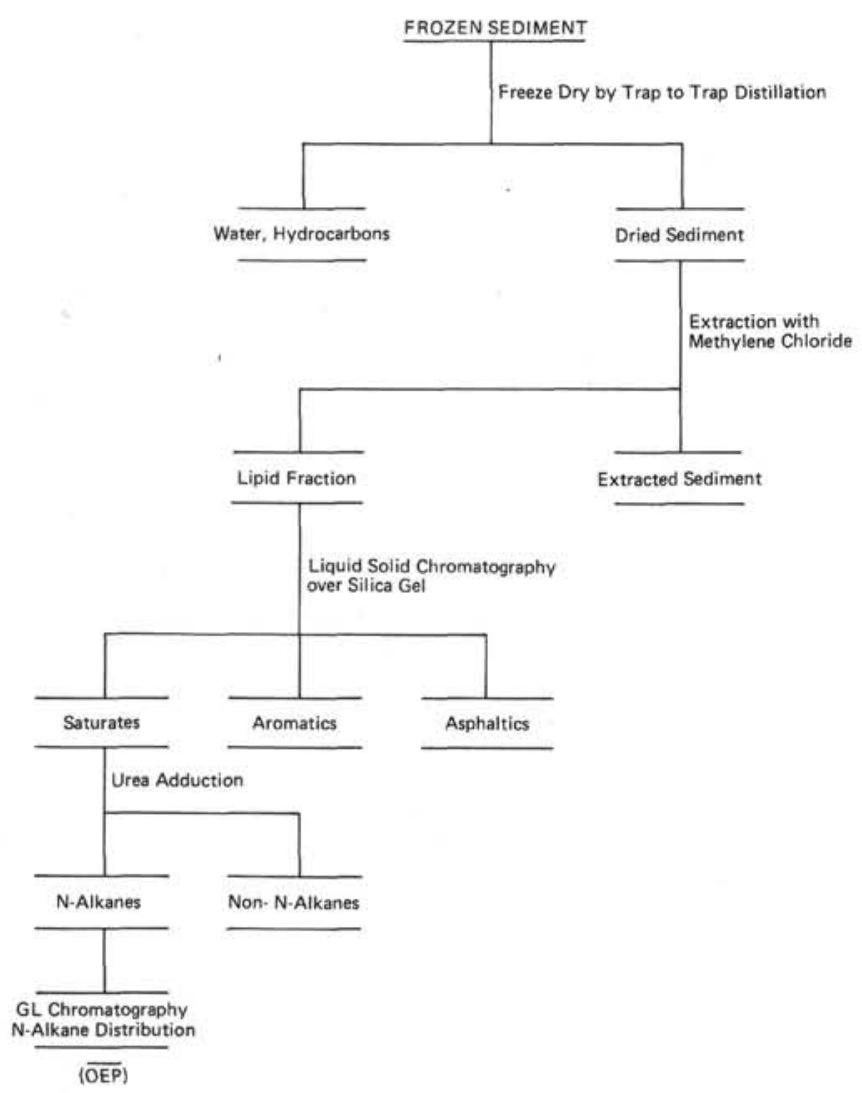

Figure 2. Flow sheet for the separation and characterization of organic matter from DSDP cores from Legs $42 A$ and $42 B$.

history. The ratio of odd-to-even $n$-alkanes as given by the OEP value, that is, the average value of the ratio of odd-to-even $n$-alkanes from $\mathrm{C}_{23}$ to $\mathrm{C}_{33}$ in Table 2 is indicative of an early stage of organic diagenesis.

At Hole 378 samples studied were of Pliocene age at 143.9 meters, of Quaternary age at 51.9 meters and of Pliocene age at 297.4 meters in the offset Hole 378A.
All three intervals contained approximately equal amounts of organic carbon, averaging $0.7 \pm 0.1 \%$. The carbon isotopic compositions of the lipid and kerogen fractions for both the Quaternary from Hole 378A and Pliocene from Hole 378 were each identical within experimental error, that is, $-26.4 \pm 0.2 \delta \mathrm{C}^{13}{ }_{\mathrm{PDB}}$ for the lipid fraction and $-23.1 \pm 0.1 \delta \mathrm{C}^{13}{ }_{\mathrm{PDB}}$ for the kerogen fraction. These values are indicative of organic matter deposited in a marine environment. The sediment samples also contained similar amounts of carbonate carbon, namely $38 \%$ and $40 \%$ as calcium carbonate, respectively. The Pliocene sediments at Hole 378 contained approximately 10 times more lipid carbon and slightly more inorganic (ammonia) and organic nitrogen as determined by the full and half Kjeldahls than both the Quaternary and Pliocene sediments from Hole 378A, Table 1 and 2. The Pliocene samples at Hole 378A differed from both the Quaternary samples at Hole $378 \mathrm{~A}$ and the Pliocene samples at Hole 378 with respect to the carbon isotopic composition of the lipid fraction. In this case, the value was -30.0 as compared to -26.6 and $-26.3 \delta \mathrm{C}^{13}$ PDB respectively. The lithology was gypsum as compared to the calcareous marls for both the Quaternary at Hole 378A or the Pliocene from Hole 378 . The ratio of $n$-alkanes as given by the $\overline{\mathrm{OEP}}$ value in Table 2 for the Pliocene from Hole 378 is typical of an early stage of diagenesis. The $n$ alkane content for both the Quaternary and Pliocene from Hole 378A was too low for this determination.

Ten Pleistocene cores ranging in depth from 29.4 to 1039.2 meters were studied from Hole 380 and the offset Hole 380A. The organic carbon content was high, that is greater than $0.9 \%$ for all but the terrigenous mud sample, 380-4-0. The carbon isotopic composition of the lipid fractions from samples from 29.4 to 228.0 meters ranged from -29.1 and -31.1 $\delta \mathrm{C}^{13}{ }_{\mathrm{PDB}}$, typical of brackish and fresh-water environments, to a relatively constant value of $-27.8 \pm 1.0$ $\delta \mathrm{C}^{13}$ PDB. An exception was the 927.9-meter section whose lipid fraction exhibited a carbon isotopic value typical of an open marine environment of deposition. A 
TABLE 2

Geochemical Characterization Data for Samples From DSDP Leg 42A and 42B for Lipid Fraction

\begin{tabular}{|c|c|c|c|c|c|c|c|c|c|c|c|c|c|c|c|c|}
\hline \multirow{3}{*}{$\begin{array}{l}\text { Site-Core- } \\
\text { Section }\end{array}$} & \multirow{3}{*}{$\begin{array}{c}\text { Lipid/Total } \\
\text { Org. C } \\
\text { (wt \%) }\end{array}$} & \multirow{2}{*}{\multicolumn{9}{|c|}{$\begin{array}{c}\text { Total Lipid } \\
\text { Elemental Composition }\end{array}$}} & \multicolumn{5}{|c|}{ Lipid Fractions } & \multirow[b]{3}{*}{$\overline{\mathrm{OE}}$} \\
\hline & & & & & & & & & & & \multirow{2}{*}{$\begin{array}{c}\text { Saturate } \\
\text { (wt \%) }\end{array}$} & \multicolumn{2}{|c|}{ Aromatic } & \multicolumn{2}{|c|}{ Asphaltic } & \\
\hline & & $\mathrm{C}$ & $\mathrm{H}$ & $\mathrm{N}$ & $\mathrm{S}$ & $\mathrm{O}^{\mathrm{a}}$ & $\mathrm{H} / \mathrm{C}$ & $\mathrm{N} / \mathrm{C}$ & $\mathrm{S} / \mathrm{C}$ & $\delta \mathrm{C}^{13} \mathrm{PDB}$ & & (wt \%) & $\left(\delta \mathrm{C}^{13} \mathrm{PDB}\right)$ & (wt \%) & $\left(8 \mathrm{C}^{13}\right.$ PDB $)$ & \\
\hline $376-9-2$ & 1.28 & b & b & b & b & & & & & -22.9 & 13.0 & 20.4 & -25.9 & 66.6 & -21.8 & 3.6 \\
\hline $378-6-2$ & 2.51 & b & b & b & b & & & & & -26.3 & 59.7 & 12.5 & -23.6 & 27.8 & -25.4 & 4.7 \\
\hline $378 \mathrm{~A}-1-4$ & 0.18 & b & b & b & b & & & & & -26.6 & $\mathrm{~b}$ & b & b & b & b & b \\
\hline $378 \mathrm{~A}-3-3$ & 0.21 & b & b & b & b & & & & & -30.0 & b & b & b & b & b & b \\
\hline $380-4-0$ & 2.96 & b & b & b & b & & & & & -29.1 & 22.7 & 49.7 & -26.8 & 27.6 & -28.2 & b \\
\hline $380-25-0$ & 2.02 & b & b & b & b & & & & & -31.1 & 25.8 & 56.0 & -31.7 & 18.2 & -28.2 & 6.2 \\
\hline $380 A-3-3$ & 5.30 & b & b & b & b & & & & & -28.0 & 11.5 & 8.2 & -28.5 & 80.3 & -27.7 & 7.3 \\
\hline $380 \mathrm{~A}-12-1$ & 2.22 & b & b & b & b & & & & & -28.7 & 14.0 & 62.5 & -28.6 & 23.5 & -29.1 & 7.3 \\
\hline $380 \mathrm{~A}-22-4$ & 2.75 & 79.68 & 12.22 & 0.29 & 4.87 & 2.94 & 1.83 & 0.003 & 0.023 & -27.2 & 8.7 & 7.7 & -27.2 & 83.6 & -26.7 & 5.3 \\
\hline $380 \mathrm{~A}-38-4$ & 2.11 & 72.41 & 11.09 & 0.23 & 10.39 & 5.88 & 1.82 & 0.003 & 0.054 & -28.1 & 18.6 & 9.1 & -27.4 & 72.3 & -28.1 & 4.9 \\
\hline $380 A-47-4$ & 2.68 & 80.42 & 12.21 & 0.54 & 3.45 & 3.38 & 1.81 & 0.006 & 0.016 & -27.7 & 8.2 & 11.4 & -23.3 & 80.4 & -27.0 & 5.8 \\
\hline $380 A-55-2$ & 2.69 & 81.52 & 12.42 & 0.34 & 0.92 & 4.80 & 1.81 & 0.004 & 0.004 & -27.3 & 6.5 & 15.8 & -29.6 & 77.7 & -26.8 & 6.0 \\
\hline $380 \mathrm{~A}-64-5$ & 3.55 & 81.36 & 12.45 & 0.17 & 1.10 & 4.92 & 1.82 & 0.002 & 0.005 & -22.6 & 0.3 & 29.3 & -22.4 & 70.4 & -23.1 & b \\
\hline $380 \mathrm{~A}-76-3$ & 1.08 & b & b & $\mathrm{b}$ & b & & & & & -26.8 & 31.8 & 33.4 & -26.5 & 34.8 & -26.3 & 5.6 \\
\hline
\end{tabular}

${ }^{\mathrm{a}}$ Insufficient sample for analysis. In all cases of the saturate fraction, priority was given to determination of OEP rather than carbon isotopic composition.

$\mathrm{b}$ Oxygen was determined by difference.

${ }^{\mathrm{R}} \mathrm{Ratio}$ of odd-to-even $n$-alkanes from $\mathrm{C}_{23}$ to $\mathrm{C}_{33}$. 


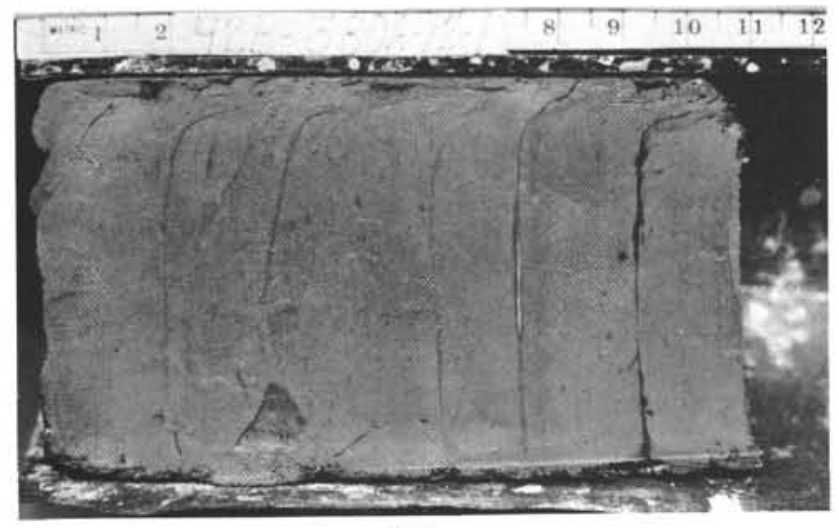

(A)
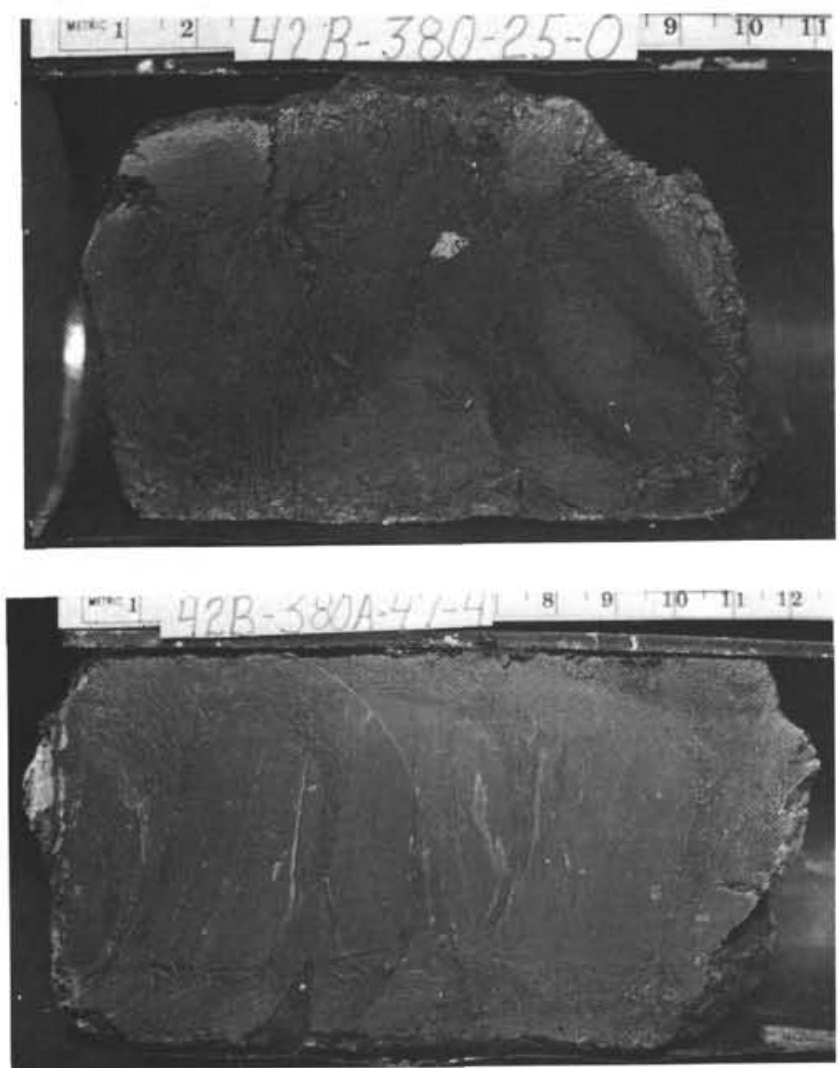

(B)

Figure 3. Drilling disturbances observed in DSPI samples. (A) A typical drilling disturbance is observed as a slight distortion of the core at the sleeve-core interface. (B) Extensive drilling disturbance is observed as either large lumps of one sedimentary unit admixed with a second as illustrated by Section 42B-380-35-0 or by one unit squeezing along the sides of the core sleeve and periodically penetrating into the core as illustrated by Section $42 B-380 A-47-4$.

slight trend with depth to heavier isotope ratio values is observed in this suite.

A periodic re-occurrence of high carbonate carbon content is observed at depths ranging from 438.0 to 1039.2 meters (Table 1). The carbonate carbon content varies from an average high of $2.0 \%$ (17.5\% as calcium carbonate) to an average low of $0.4 \%(3.3 \%$ as calcium carbonate).

The total organic nitrogen content as determined by difference by subtracting the half from the full Kjeldahl varies with the organic carbon content as shown in Table 1. The nitrogen content ranged from a low of 187 $\mathrm{ppm}$ for the organic lean terrigenous mud to $1420 \mathrm{ppm}$ for the organic-rich sediment Section 380A-55-2. The increase in total organic nitrogen with organic content has been observed in other DSDP sediments from Legs 40 and 41 (Erdman and Schorno, in press).

The carbon to hydrogen ratios for the lipid fractions of Sections 380A-22-4 through 380A-64-5 were identical within experimental error, averaging 1.82 \pm 0.01 . The nitrogen to carbon ratios of these lipid fractions are relatively constant averaging 0.004 and are within the range of other DSDP samples from Legs 40 and 41 . The sulfur to carbon ratios vary from a high of 0.054 to a low of 0.005 trending to lower values with depth.

Some similarities are observed in the saturate, aromatic, and asphaltic fractions of the Pleistocene suite from Hole $380 \mathrm{~A}$ in that the asphaltic content is relatively high, $77 \pm 6 \%$, for six out of the eight cores; whereas, the two Pleistocene sediments from Hole 380 were relatively low, $23 \pm 5 \%$.

\section{CONCLUSIONS}

All sediments studied from the five sites contain sufficient organic matter to qualify as potential source

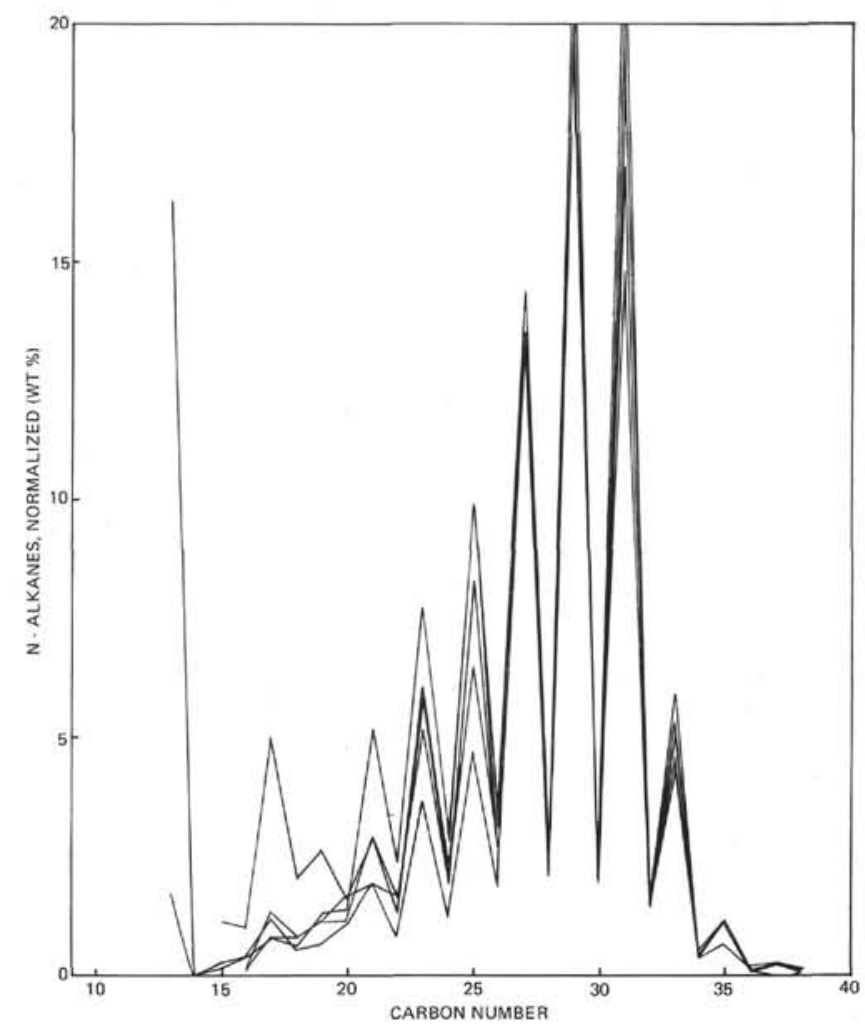

Figure 4. Normalized n-alkane versus carbon number plots from the Pleistocene Sections 380A-3-3, 380A-22-4 through 380A-55-2. 
beds for petroleum according to Philippi (1956). The high ratios of odd-to-even $n$-alkanes as given by the $\overline{\mathrm{OEP}}$ value, however, indicate that the petroleum genesis is in a very early stage.

The carbon isotopic compositions of the lipid fractions provide an index to the contribution of terrigenous matter to the environment of deposition. The isotope values for the upper Miocene section of Site 376 indicated that the depositional environment was open marine with very little input of organic matter of terrigenous origin. To the northwest in the Cretan Basin the Quaternary and Pliocene calcareous sections at Holes 378 and $378 \mathrm{~A}$ were deposited in a marine environment with a small but significant contribution of terrigenous organic matter. In contrast, the deeper lying Pliocene sediments from Hole 378A received a large terrigenous contribution. The environment of deposition for the Pleistocene from Holes 380 and 380A varied from fresh to brackish to open marine. In general the $\overline{\mathrm{OEP}}$ values at Holes 380 and $380 \mathrm{~A}$ were extremely high (Figure 4), probably indicating a combina- tion of a very early stage of genesis and a large terrestrial contribution to the sedimentary organic matter.

\section{ACKNOWLEDGMENT}

The authors thank J. Whelan, the Woods Hole Oceanographic Institution, for her review and suggestions concerning the manuscript and to C.P. Elston, Phillips Research Center, for her help in obtaining and assembling data presented herein.

\section{REFERENCES}

Erdman, J.G. and Schorno, K.S., in press. Geochemistry of carbon: Deep Sea Drilling Project Leg 41. In Lancelot, Y., Seibold, E., et al., Initial Reports of the Deep Sea Drilling Project, Volume 41: Washington (U.S. Government Printing Office).

Philippi, G.T., 1956. Identification of oil source beds by chemical means: Twentieth Internat. Geol. Congr. Sect. III, p. 25-38. 